Tropical Journal of Pharmaceutical Research, March 2007; 6 (1): 679-682

(C) Pharmacotherapy Group, Faculty of Pharmacy, University of Benin Benin City, Nigeria.

All rights reserved.

Report

Available online at http://www.tjpr.org

\title{
In vitro Antimicrobial Activity of the Extract of Mitracarpus scaber Leaves Formulated as Syrup
}

\author{
TA Abere ${ }^{1^{*}}$, AO Onyekweli ${ }^{2}$, and GC Ukoh ${ }^{3}$ \\ ${ }^{1}$ Department of Pharmacognosy. ${ }^{2}$ Department of Pharmaceutics and Pharmaceutical Technology. ${ }^{3}$ Department of \\ Pharmaceutical Microbiology. Faculty of Pharmacy, University of Benin, PMB 1154, Benin-City, Nigeria.
}

\begin{abstract}
Purpose: To formulate the crude extract of the leaves of Mitracarpus scarber "Zucc" as a syrup.

Method: The antimicrobial activity of the formulation was assessed using agar plates and concentrations of the extract varying between $25 \mathrm{mg} / \mathrm{ml}$ and $300 \mathrm{mg} / \mathrm{ml}$ to determine the minimum inhibitory concentration at $37^{\circ} \mathrm{C}$ against bacterial and fungal organisms namely, Escherichia coli, Pseudomonas aeruginosa, Staphylococcus aureus, Sarcina lutea, Candida albicans and Klebsiella pneumoniae.

Result: The growth of Escherichia coli, Staphylococcus aureus, Klebsiella pneumoniae and Candida albicans was inhibited by the formulation at a minimum inhibitory concentration of $75 \mathrm{mg} / \mathrm{ml}$. Pseudomonas aeruginosa, and Sarcina lutea resisted all the concentrations of the formulation used. The presence of sucrose in the formulation rendered the formulation pleasant to taste.

Conclusion: The extract from the leaves of Mitracarpus scarber "Zucc" can be formulated into a pleasantly tasting oral dosage form despite its bitter taste.
\end{abstract}

Keywords: Antimicrobial, Mitracarpus scaber, syrup, formulation, minimum inhibitory concentration.

*Correspondence E-mail : eseabere@yahoo.com 


\section{INTRODUCTION}

The yearly Herbal Medicine Trade Fair in Nigeria and the increasing publicity and patronage this attracts, irrespective of the social, educational or religious background of the people are indicative of acceptance of herbal medical practice ${ }^{1}$. The setting up of Traditional Medicine Board by some State Governments in our country and the on-going registration of herbal products by National Agency for Food, Drug Administration and Control (NAFDAC) are equally indicative of recognition by the Government.

Some drugs of plant origin in conventional medical practice are not pure compounds but direct extracts or plant materials that have been suitably prepared and standardized ${ }^{2}$. Recently the World Health Organization (WHO) has recommended the use of Arthemisinin derivatives derived from Artemisia annua (Composite), a Chinese herb, as a first line drug in the treatment of malaria ${ }^{3,4}$. This is as a result of WHO's recognition that $80 \%$ of world population use herbal medicine for some aspect of Primary Health Care ${ }^{5}$.

The plant family, Rubiaceae, which parades a long list of plants of medicinal importance, has Mitracarpus scarber "Zucc" as example ${ }^{6,7}$. It is claimed that it possesses antimicrobial activities when crude extracts from the plant is used ${ }^{7-10}$. Ahonkhai et $a l^{11}$ formulated the crude extracts from the leaves as soap solution but it was observed that the availability of the antimicrobial principle was hindered by the soap. This was attributed to uptake of the active principle by the soap. This suggests that a new formulation is needed. This study, therefore, aims at establishing a simple formulation that does not hinder the availability of the active principles from the product. Considering that this extract is ingested in the treatment of sore throat and other upper respiratory diseases, URD, ${ }^{12}$ despite its bitter taste, this study also aims at formulating the crude extract into a pleasant oral dosage form.

\section{MATERIALS AND METHODS}

Laboratory grades of Petroleum ether and methanol from British Drug Houses (BDH) as well as Granulated Sugar purchased from the open market were used. The following media, Blood Agar (Oxoid 271), Nutrient Agar (Oxoid) and Sabouraud Agar (Oxoid) were equally provided for microbial studies.

The plant was collected locally in Benin-City, Nigeria, identified and authenticated as Mitracarpus scarber "Zucc", family Rubiaceae, by the plant curator of the Herbarium, Department of Pharmacognosy, Faculty of Pharmacy University of Benin, Benin-City, Nigeria, where a voucher specimen of the plant is deposited. It was sun dried and powdered using Moulinex mill after which it was stored in a dry and wellstoppered bottle.

The organisms used were clinical isolates of Escherichia coli, Pseudomonas aeruginosa, Staphylococcus aureus, Klebsiella pneumoniae, Candida albicans and Sarcina lutea (from the University of Benin Teaching Hospital, Benin-City), Escherichia coli (NCTC 10418) and Staphylococcus aureus (NCTC 6751) typed cultures.

\section{Preparation of the Crude extract}

$1.5 \mathrm{~kg}$ of the powdered plant material in each batch was exhaustively extracted by soxhlet extraction method using either Petroleum ether, (A), or Methanol, (B), or $70 \% \mathrm{v} / \mathrm{v}$ Methanol in $\mathrm{H}_{2} \mathrm{O}$, (C). The solvent used in each batch was recovered under pressure until dry extracts were obtained and then stored separately in amber colored bottles labeled as A, B and C.

\section{Preparation of Syrup and Simple solutions}

The B. P. method ${ }^{13}$ was adopted to prepare simple syrup, which was used as diluent to prepare concentrations of the crude extracts, (A, B and C) varying between $25 \mathrm{mg} / \mathrm{ml}$ and $300 \mathrm{mg} / \mathrm{ml}$ from stock solution, $500 \mathrm{mg} / \mathrm{ml}$. For Simple solution, distilled 
Table 1: Sensitivity of Extract Samples (A, B \& C) at $75 \mathrm{mg} / \mathrm{ml}$ on Test Organisms

\begin{tabular}{lcc}
\hline & \multicolumn{2}{c}{${ }^{\#}$ Zone of Inhibition (Mean) } \\
\cline { 2 - 3 } Test Organisms & $\begin{array}{c}\text { Simple } \\
\text { Solution }\end{array}$ & $\begin{array}{c}\text { Extract in } \\
\text { Syrup }\end{array}$ \\
\hline${ }^{*}$ C. albicans & $22 \mathrm{~mm}$ & $22 \mathrm{~mm}$ \\
E. coli (NCTC & $21 \mathrm{~mm}$ & $21 \mathrm{~mm}$ \\
$10418)$ & & \\
S. aureus & $28 \mathrm{~mm}$ & $28 \mathrm{~mm}$ \\
$($ NCTC 6751) & & \\
${ }^{*}$ E. coli & $20 \mathrm{~mm}$ & $20 \mathrm{~mm}$ \\
${ }^{*}$ K. pneumoniae & $23 \mathrm{~mm}$ & $22 \mathrm{~mm}$ \\
${ }^{*}$ PS. aeruginosa & nil & Nil \\
${ }^{*}$ S. aureus & $27 \mathrm{~mm}$ & $26 \mathrm{~mm}$ \\
${ }^{*}$ Sarcina lutea & nil & Nil \\
\hline
\end{tabular}

*:Clinical isolates.

\#: Mean zone diameters from two replicates are recorded

water was used as diluent to prepare the same concentrations.

\section{Antimicrobial activity of the Extract}

All the extracts were first screened for antimicrobial activity by the Well plate method ${ }^{14}$. Nutrient and Sabouraud agar plates were seeded with overnight cultures of the test organisms namely Escherichia coli (NCTC 10418), Staphylococcus aureus (NCTC 6751) and clinical isolates of Escherichia coli, Pseudomonas aeruginosa, Staphylococcus aureus, Klebsiella pneumoniae, Candida albicans and Sarcina lutea. Wells, $15 \mathrm{~mm}$ wide, were cut in the agar plates with cork borer and $1.5 \mathrm{mls}$ of the different extracts were pipetted and carefully added to the wells. The Nutrient agar plates were incubated right side up at $37^{\circ} \mathrm{C}$ for $24 \mathrm{hrs}$ while the Sabouraud agar plate was incubated at room temperature for $48 \mathrm{hrs}$. The zones of inhibition were then measured and the mean of two replicates recorded.

\section{Minimum Inhibitory Concentration of Extract in Syrup}

The minimum inhibitory concentration was determined by Agar dilution method ${ }^{15}$. A $1 \mathrm{gm} / \mathrm{ml}$ and $500 \mathrm{mg} / \mathrm{ml}$ dilution of each of the extract were made in water. From these stocks, graded concentrations of the extracts in syrup were made to achieve $25 \mathrm{mg} / \mathrm{ml}, 50 \mathrm{mg} / \mathrm{ml}, 75 \mathrm{mg} / \mathrm{ml}$, $100 \mathrm{mg} / \mathrm{ml}, 200 \mathrm{mg} / \mathrm{ml}$ and $300 \mathrm{mg} / \mathrm{ml}$ final concentrations in $20 \mathrm{mls}$ of both Nutrient and Sabouraud agar plates. These plates were spotted with $0.1 \mathrm{ml}$ overnight cultures of the test organisms. The Nutrient agar plates were incubated right side up at $37^{\circ} \mathrm{C}$ for 24 hours while the Sabouraud agar plates were incubated at room temperature for $\mathbf{4 8}$ hours. The zones of inhibition were measured from two replicates and the mean recorded.

\section{RESULTS}

In the Table, the antimicrobial activity of the water extract (simple solution) of Mitracarpus scarber "Zucc" was demonstrated. All the samples inhibited the growth of most of the organisms. It also shows the sensitivity of the syrup samples prepared using the different extraction methods. It therefore indicates that the method of extraction did not affect the sensitivity of the active principles of the extract present in the formulation. Also formulating the extract as syrup did not alter their sensitivity. The minimum inhibitory concentration (MIC) of the extract in syrup was also determined. Irrespective of the method of extraction of the crude extract, all the syrup formulations were 


\section{Abere et al}

active at $75 \mathrm{mg} / \mathrm{ml}$ against all organisms used except Pseudomonas aeruginosa and Sarcina lutea which grew even at a high concentration of $300 \mathrm{mg} / \mathrm{ml}$. It is equally interesting to note that Candida albicans was inhibited at $75 \mathrm{mg} / \mathrm{ml}$.

\section{DISCUSSION}

Reports have shown that the extract of Mitracarpus scarber "Zucc" has antibacterial and antifungal activities ${ }^{8,11}$, and 16 . This work equally has confirmed such findings. Although Ahonkhai, et. al ${ }^{11}$ stated that application of heat in the extraction method may have affected the potency of the antifungal principle(s), this work has shown that application of heat to the various extracts did not affect the activity of the extract to both bacterial and fungal organisms in the different formulations. Rather the inhibition to growth of the organisms by the extracts can be attributed to the potency of active principles as well as the strain and possibly, weakness in strength of organism used. Previous work ${ }^{11}$ demonstrated that the extract had low activity over Pseudomonas aeruginosa despite the fact that this organism is known to be a very recalcitrant gram-negative organism. This work equally confirms that. This further confirms that heating may not be responsible for the insensitivity shown.

Formulating this extract, as Syrup did not hinder the diffusion of the active principle(s) in the formulation hence the zones of inhibition at $75 \mathrm{mg} / \mathrm{ml}$ recorded for both the simple solution and the syrup were the same. Sucrose, a sweetening agent and main content of syrup, has been used to mask the bitter taste of the extract and so, a pleasantly tasting oral dosage form of the extract was easily formulated. Extract of Mitracarpus scarber "Zucc" can, therefore, be formulated as simple syrup.

\section{REFERENCES}

1. Ukwuomah B, Da Costa K. "Government may soon formulate Crude Drugs Herbal Policy" In: The Guardian Newspaper (Nigeria), October $3^{\text {rd }}, 1997$. pp 4

2. Donald EU. Medicinal plants research in Nigeria: Retrospect and Prospects. In: Sofowora (ed). The state of Medicinal Plants Research in Nigeria. Copyright (c) Nigerian Society of Pharmacognosy, Ibadan University Press, Nigeria, 1986, pp $1-12$.
3. World Health Organization (WHO). Antimalarials Drug Combination Therapy: Report of a WHO Technical Consultation, April 2001, pp 1-2.

4. World Health Organization. WHO urges Countries to act on New Anti-Resistance Malaria Medicines. Press release WHO/31, April 2002, pp 1 - 3.

5. Farnsworth $\mathrm{H}$, Akerele O. Bulletin of the WHO 1985, 3(6): $965-982$.

6. Oliver BEP. Medicinal Plants in Nigeria. Private Edition, Published by The Nigerian College of Arts, Science and Technology, Lagos, Nigeria, 1959 pp $17-41$

7. Gill S. Ethnomedical uses of Plants in Nigeria. University of Benin Press, Benin City, Nigeria, 1992, pp 162.

8. Benjamín TV, Anucha TC, Hugbo PG. An approach to the study of Medicinal plants with antimicrobial activity with reference to Mitracarpus scarber. In: Sofowora (ed). The state of Medicinal Plants Research in Nigeria. Copyright (c) Nigerian Society of Pharmacognosy, Ibadan University Press, Nigeria, 1986, pp $243-251$.

9. Irobi ON, Daramola SO. Antifungal activities of crude extracts of Mitracarpus villous (Rubiaceae). J. Ethnopharmacology 1993; 40: 137 - 140.

10. Irobi ON, Daramola SO. Bacterial properties of crude extracts of Mitracarpus villous (Rubiaceae). J. Ethnopharmacology 1994; 42: 39 - 43.

11. Ahonkhai IA, Onyekweli AO, Ibe IE. Antimicrobial activity of the crude extract of Mitracarpus scarber "ZUCC" in a liquid soap (shampoo) formulation. Nig. J. Appl. Sci. 1999; 17: 115 - 120.

12. Fluck H. Medicinal Plants and their uses. W. Foulsman and Co. Ltd, England, 1976, pp 41, 46 and 114.

13. British Pharmacopoea. 1980, pp 725.

14. Hugo WB. Disinfectant evaluation. In: Hugo WB (ed). Disinfection monograph. Heinemann. London, 1975, pp. $24-29$.

15. Hugo WB, Russel AD. Pharmaceutical Microbiology. Blackwell Scientific Publications, Oxford, 1981, pp 190

16. Bisignano $G$, Sanogo $R$, Marno A, Aquino $R$, D'Angelo $V$, Germano $M P$, De Pasquale $R$, Pizza $C$. Antimicrobial activity of Mitracarpus scarber extract and isolated constituents. Letters in Applied Microbiology 2000; 30 (2): 105 - 108. 